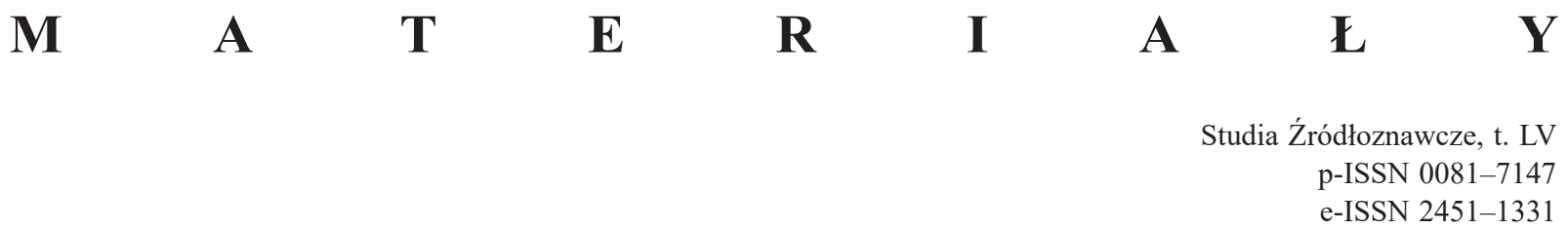

Mariusz LEŃCZUK

Instytut Języka Polskiego PAN

\title{
Dwa staropolskie zaklęcia z XV w.
}

Zarys treści: Artykuł przedstawia dwa staropolskie zaklęcia: przeciwko jadowitym robakom oraz przeciwko wściekliźnie, odnalezione w rękopisie z końca XV w. należącym do Archiwum Prowincji oo. Dominikanów w Krakowie (sygn. R.XV.3). Tego rodzaju teksty należą do rzadkości. Do tej pory odnaleziono i opublikowano zaledwie trzy fragmenty średniowiecznych magicznych formuł zapisanych $w$ języku polskim, które odkryto jeszcze w XIX w. Dominikańskie inkantacje są wyjątkowe zarówno z uwagi na fakt, że zachowały się w całości, jak i na specyfikę użytego w nich języka. Celem artykułu jest edycja dwóch nieznanych średniowiecznych zabytków języka polskiego.

\begin{abstract}
The article presents two old-Polish magic spells: against venomous worms and against rabies found in a manuscript of the late fifteenth century, kept in the Archives of the Polish Province of the Dominicans in Cracow, ref. no. R.XV.3. The text of such type are very rare. Only three fragments of medieval magic spells written in Polish have been found; and the discovery was made in the nineteenth century. The Dominican incantations are unusual both because they have been completely preserved, and because of the used language. The purpose of the article is to publish the two unknown medieval monuments of the Polish language.
\end{abstract}

Słowa kluczowe: język staropolski, rękopisy XV-wieczne, modlitwa, formuła magiczna, zaklęcie

Keywords: Old Polish language, $15^{\text {th }}$-century manuscripts, oratio, magic formula, incantatio

Wśród nieznanych dotąd tekstów piśmiennictwa staropolskiego należy wymienić dwa zaklęcia1: przeciwko jadowitym robakom oraz przeciwko wściekliźnie, zapisane na k. 192r-v rękopisu Archiwum Polskiej Prowincji oo. Dominikanów w Krakowie o sygn. R.XV.3. Jest to księga o wymiarach 15,2 $\mathrm{x}$ $10,5 \mathrm{~cm}$, licząca 237 papierowych numerowanych kart. Ma odrestaurowaną oprawę - deski obciągnięte w ciemnobrązową skórę z tłoczeniami - na rogach której umiejscowiono metalowe guzy ochronne w kształcie kwiatów z sześcioma płatkami. Dodatkowo na tylnej okładce znajduje się guz w polu centralnym oraz dwa mniejsze guzy przy mocowaniu zapinki.

Rękopis zachował się w dość dobrym stanie. Zawartość sugeruje, że mógł służyć jako kolektarz, ponieważ zawiera przede wszystkim modlitwy i formuły modlitewne na różnego rodzaju okazje ${ }^{2}$. Manuskrypt rozpoczyna się kalendarzem (k. 1v-6r), w którym brak jest fragmentu od końca czerwca do końca października; kolejne karty wypełniają modlitwy podzielone na części: de tempore (k. 9r-59r), de sanctis (k. 59r-110r), de communi sanctorum (k. 110v-115r) oraz agenda (k. 116r-158v). W dalszej

\footnotetext{
${ }^{1} \mathrm{Z}$ uwagi na wymiennie stosowane w literaturze przedmiotu terminy odnoszące się do tego typu tekstów w artykule równolegle użyto określeń: zaklęcie, zamawianie, formuła modlitewna, inkantacja, oratio.

${ }^{2}$ Bardzo dziękuję dr Annie Zajchowskiej za udostępnienie wstępnego opisu zawartości rękopisu.
} 
części kodeksu zapisano m.in. Orędzie paschalne - tzw. Exsultet wraz z notacją (k. 159r-177v), liczne prefacje z notacjami (k. 178r-189r), hymn Rex sanctorum angelorum (k. 189v), łacińskie i polskie formuły zamawiań (190r-192v) oraz modlitwy na wybrane święta.

Do krakowskiego archiwum rękopis trafił po II wojnie światowej ze zbiorów dominikańskiego klasztoru w Raciborzu, jednak jego pierwotne pochodzenie należy wiązać z Wrocławiem. Wskazują na to m.in.: wymieniane w porządkach procesji nazwy kościołów pod wezwaniem św. Idziego czy św. Jana Chrzciciela (ad S. Egidum - k. 39r, 48r, 51v; ad sanctum Johannem - k. 46v), umiejscowiony na początkowych kartach kalendarz diecezji wrocławskiej oraz znajdujące się w drugiej części manuskryptu (k. 161r-191r) notacje muzyczne charakterystyczne dla zapisów wrocławskich ${ }^{3}$.

Inną wskazówką proweniencyjną, wiążącą rękopis ze Śląskiem, jest podpis właściciela książki, księdza Wacława Zielińskiego z Gliwic (Venceslaus Zelinius Glivicensis), proboszcza w Nowej Cerekwi ${ }^{4}$, oddalonej o 27 km od Raciborza, który żył na początku XVII w. Jego autograf widnieje na dwóch kartach i opatrzony jest datami 1504 (k. 7r) ${ }^{5}$ oraz 1639 (k. 9r) ${ }^{6}$. Z dostępnych danych oraz duktu pisma można wnioskować, że pierwszy wpis - 1504 - był omyłkowy i należałoby go poprawić na $1604 \mathrm{r}$. Innych wskazówek proweniencyjnych w rękopisie brak.

Wykorzystany w kodeksie papier pochodzi z lat 1466-14777. Można więc bezpiecznie przyjąć, że manuskrypt zapisywany był w ostatniej ćwierci XV w. Liczba rąk pisarskich nie pozostawia wątpliwości, że nie było to dzieło jednej osoby, ale raczej kilkunastu. Większość tekstów pisana jest charakterystyczną piętnastowieczną kursywą (cursiva libraria, cursiva currens). Ta sama ręka, która na kartach 190r-192v zapisała łacińskie i polskie formuły zamawiań, na k. 144v skreśliła również modlitwę Benedictio nove domus. Jej dukt pisma jest odmienny od pozostałej części kolektarza i zbliżony jest do semihybridy currens. Pismo jest bardziej rozciągnięte, pochylone i mniej staranne, co może sugerować albo pośpiech piszącego, albo późniejszy czas wpisywania wymienionych tekstów. Wszelkie charakterystyczne cechy pisma wskazują na to, że pisarz uczył się XV-wiecznej kaligrafii, jednak wymienione powyżej właściwości duktu mogą przesuwać czas zapisu inkantacji na początek XVI w., co oczywiście nie umniejsza unikatowości znaleziska.

Staropolskie formuły zamawiań należą do rzadkości, czego dowodem są zaledwie trzy zachowane fragmenty zaklęć z końca XV w., odkryte i wydane przez Aleksandra Brücknera ${ }^{8}$. Zapisano je na k. 218v rękopisu Biblioteki Narodowej w Warszawie o sygn. 3030/I ${ }^{9}$. Poniżej przytaczam je w transkrypcji:

1. Zarze, zarzyce trzy siestrzyce...

2. Poszła Matka Boża po morzu zbirając złote pianki.

Potkat ja święty Jan:

- A gdzie jidziesz matuchno?

- Ide synaczka swego leczyć.

3. Ruskiego ${ }^{10}$ masta, jako przez tego ludzie być nie moga, tako aby ty nie byt przez mnie...

\footnotetext{
${ }^{3}$ Por. H.I. Siekierka, Notacje monodii chorałowej na Śląsu na podstawie kodeksów Biblioteki Kapitulnej we Wrocławiu. Studium paleograficzno-semiologiczne, Lublin 2011, s. 35-66.

${ }^{4}$ W rkpsie Nova Catholica; por. J. Rajman, Koźle w średniowieczu, „Studia Śląskie”, 59, 2000, s. 48.

${ }^{5}$ Ego Venceslaus Zelinius Anno domini 1504 in festo sancti Mathiae apostoli suscepi parochiam in Nova Catholica a magnifico domino domino Georgio ab Opperstorff.

${ }^{6}$ Cathalogo inscriptus Reverendissimus Pater Venceslai Zelinis Glivicensis 1639.

7 Znaki wodne: 1. var. Piccard 66462-66465 (1475-1477), var. Piekosińki 1031 (1476): f. 5-8, 10, 186-187, 235; 2. var. Piccard 66205 (1466): f. 9, 17, 29, 32-35, 49, 53, 56-57, 60, 62, 69, 72, 76, 87, 90-91, 93, 96-98, 105, 108; 3. var. Piccard 66111-66128 (1574-1579): f. 160-161, 172-175; 4. var. Piccard 66285 (1476): f. 208, 211, 220, 231, 233-235.

${ }^{8}$ A. Brückner, Kazania średniowieczne, cz. 2, w: Rozprawy Akademii Umiejętności. Wydziat Filologiczny, t. 24, Kraków 1895 , s. 332.

9 Dawniej rękopis Cesarskiej Biblioteki Publicznej w Petersburgu o sygn. Lat.O.I.73.

${ }^{10}$ Ruskiego: możliwa też lekcja Pruskiego, Puskiego; Słownik staropolski, t. 1-11, red. S. Urbańczyk, Warszawa-Kraków 1953-2002, <http://www.pjs.ijp-pan.krakow.pl/sstp.html> [dostęp 25.07.2017]; Pwszkyego (por. tamże, t. 4, s. 167).
} 
Choć powyższe fragmenty często cytowane są w różnego rodzaju wyborach tekstów dawnych czy ludowych ${ }^{11}$, to jednak nie doczekały się filologicznego opracowania. A. Brückner, wydając te formuły przy okazji omawiania średniowiecznych zbiorów kazań, zwrócił uwagę na występujące w całej Europie identyczne motywy tematyczne i stałe schematy konstrukcyjne ${ }^{12}$. Swoje uwagi dotyczące wspólnych wzorców odniósł do kazań, zamawiań, zaklinań, zażegnywań, opowiadań oraz przesądów ludowych. Cytowane przez niego staropolskie fragmenty inkantacji zaprezentowane zostały na tle niemieckich i czeskich zaklęć, które pod względem budowy i specyfiki nie odbiegają od polskich. Niestety w jego artykule zabrakło ich filologicznej interpretacji.

Nieobecność we współczesnej literaturze analizy trzech fragmentów XV-wiecznych zaklęć świadczy o hermetyczności tekstów i trudności w ich zrozumieniu. Dodatkową przeszkodą zdaje się być również ich niekompletność ${ }^{13}$. Na tym tle odnalezione w dominikańskim kodeksie pełne inkantacje są wyjątkowe i zasługują na szczególną uwagę.

Jak wspomniano na początku artykułu, na k. 190r-192v zapisano cztery modlitewne formuły w języku łacińskim: przeciw wściekłemu psu, przeciw ugryzieniu wściekłego psa, przeciw gromom, błogosławieństwo chleba podawanego bydłu przeciw wszelkiej truciźnie (Contra rabiem venenosi canis, Contra morsum rabidi canis, Contra toniturua, Benediccio panis pro pecudibus... contra omnem venenum) i dwie w języku polskim: przeciw jadowitym robakom (Contra venenosos vermes) oraz przeciw wściekliźnie (bez łac. tytułu).

Oba staropolskie teksty są cennymi zabytkami średniowiecznej kultury piśmienniczej nie tylko z uwagi na kompletność zapisu i unikatowy charakter tego typu formuł, ale również ze względu na miejsce ich wpisania oraz język. Te niewielkich rozmiarów formuły modlitewne są świadectwem ówczesnych praktyk medycznych, które zachowały się do dziśs ${ }^{14}$. We współczesnych opracowaniach historycznych i etnograficznych często pisze się wprost o walce Kościoła z tego typu praktykami i gusłami ${ }^{15}$, jednak zapis w dominikańskim rękopisie podważa po części te twierdzenia. Na k. 190r, tuż po tytule łacińskiego zaklęcia Contra rabiem venenosi canis, widnieje wskazówka, która sugeruje, że tego typu formuły mogli odmawiać również księża: Inprimis sacerdos aut alius devotus homo dicit... Sam fakt wpisania zaklęć do kolektarza każe się zastanowić, na ile dotychczasowe sądy o wyłącznie ludowym charakterze zamawiań są prawdziwe. Przenikanie się świata chrześcijańskiego i pogańskiego wpisane było w kulturę późnego średniowiecza i niewykluczone jest, że inkantacje mogły być lokalnie aprobowane również w kręgach kościelnych. Innym wytłumaczeniem umieszczenia nietypowych modlitw w kolektarzu może być ich budowa ${ }^{16}$. Pod tym względem zaklęcia nie różnią się od zapisanych w dominikańskim rękopisie benedictiones i orationes usankcjonowanych przez Kościół. Na początku występuje w nich inwokacja: In nomine Patris et Filii, et Spiritus Sancti lub jej skrócona wersja: In nomine Domini, wewnątrz pojawiają się podstawowe modlitwy chrześcijańskie, np. Credo, a wszyst-

${ }^{11}$ M. Włodarski, Polska poezja świecka XV wieku, wyd. 4 zm., Wrocław 1997, s. 119; S. Czernik, Trzy zorze dziewicze. Wśród zamawiań $i$ zaklęć, Łódź 1968, s. 61.

12 A. Brückner, Kazania średniowieczne, s. 38-97, 317-390.

${ }^{13}$ Zachowane fragmenty w dotychczasowych wydaniach dzielone były na różne sposoby, np. A. Brückner (tamże, s. 332) wyróżnił trzy inkantacje, a M. Włodarski (tenże, Polska poezja świecka, s. 119) dwie, ponieważ połączył pierwszą i drugą.

${ }^{14}$ Por. A. Engelking, Rytuały stowne w kulturze ludowej. Próba klasyfikacji, w: Język a kultura, t. 4: [Funkcje języka $i$ wypowiedzi], red. J. Bartmiński, R. Grzegorczykowa, Wrocław 1991, s. 75-85; M. Leśniewska-Sawicka, M. Waśkow, Medycyna ludowa, gusła i zabobony jako metody lecznicze praktykowane w XXI wieku, „Medycyna Rodzinna”, 15, 2012, nr 1, s. 10-14.

15 Por. np.: S. Czernik, Trzy zorze dziewicze. Wśród zamawiań i zaklęć, wyd. 2, Łódź 1985; K. Bracha, Pismo, stowa i symbole. Pomiędzy średniowieczna pobożnościa a magią, w: Inskrypcje toruńskie, red. I. Sawicka, Toruń 1999, s. 7-24; Karolińscy pokutnicy i polskie średniowieczne czarownice. Konfrontacja doktryny chrześcijańskiej z życiem społeczeństwa średniowiecznego, red. M. Koczerska, Warszawa 2007.

${ }^{16}$ Struktura inkantacji znacząco odbiega od struktury rozpowszechnionych w XV-wiecznych rękopisach recept lekarskich i porad zamieszczonych w zielnikach, w których znajdują się rozdziały przeciw ugryzieniom jadowitych robaków czy wściekliźnie (por. S. Falimirz, O ziołach i o mocy ich, Kraków 1534, k. 30va; J. Szostak, Vademecum lecznictwa domowego z roku 1563, Brzezia Łąka 2016, s. 67), dlatego w niniejszym artykule nie zostały one poddane analizie porównawczej. O strukturze recept pisała m.in. K. Nowak, Jak dawniej leczono, czyli o akcie siedemnastowiecznej porady medycznej, w: Bogactwo polszczyzny w świetle jej historii, t. 2, red. K. Kleszczowa, A. Rejter, Katowice 2008, s. 119-130. 
kie zwieńczone są uroczystą formułą kończącą: Amen. Łacińskie i polskie zamawiania skierowane są przeciw skutkom działania złych stworzeń, co upodabnia je do egzorcyzmów. Podobnie jak zebrane w kolektarzu formuły modlitewne, zaklęcia odnoszą się do życia codziennego ówczesnych ludzi i pod tym względem rękopis stanowi spójną całość.

Poniższa edycja dwóch XV-wiecznych tekstów przygotowana została według Zasad wydawania tekstów staropolskich. Projekt ${ }^{17}$. Wszelkie wątpliwości odczytania rękopisu zasygnalizowano w przypisach, a na końcu artykułu zamieszczono indeks wyrazowy.

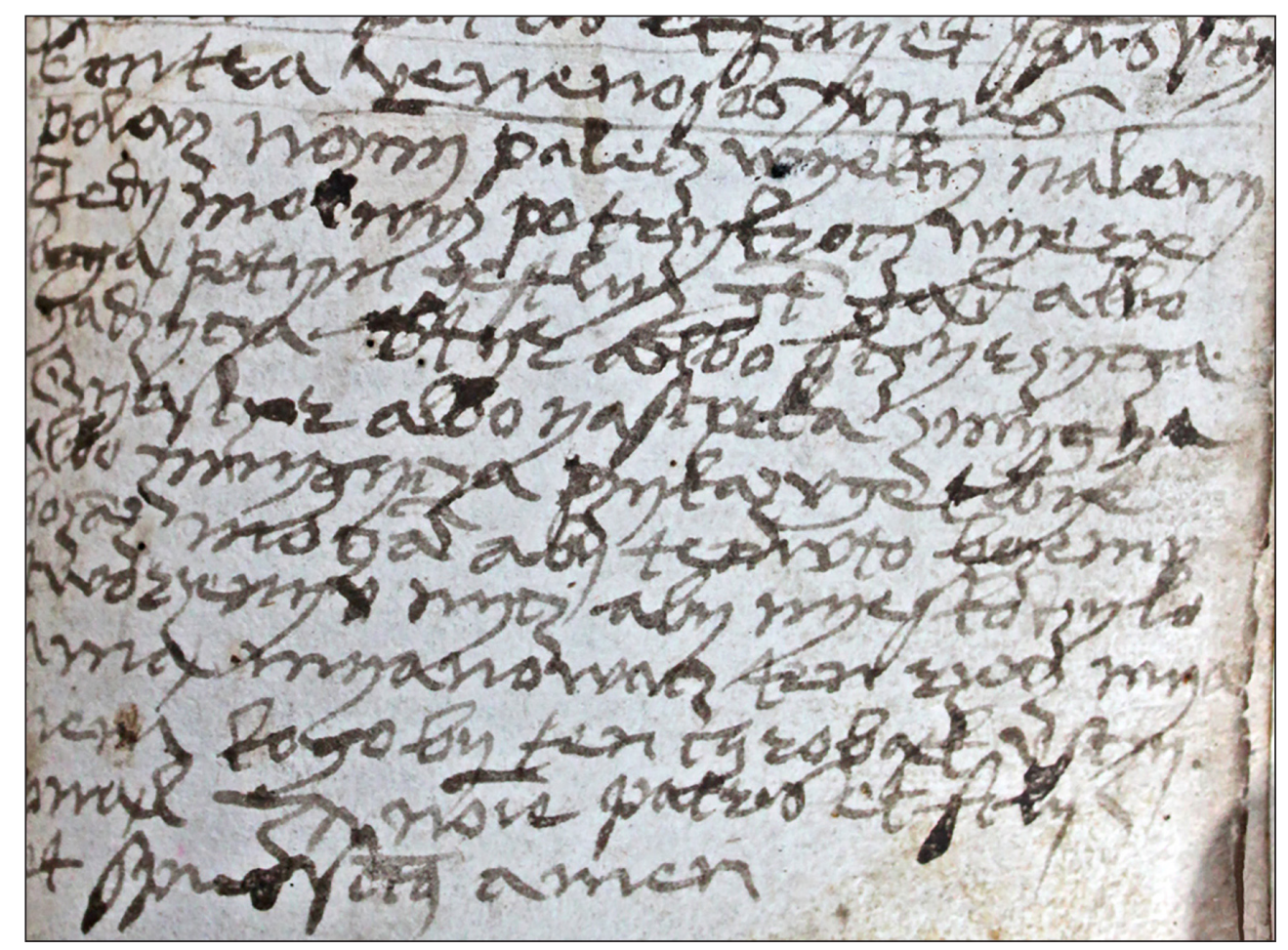

Fragment k. 192r

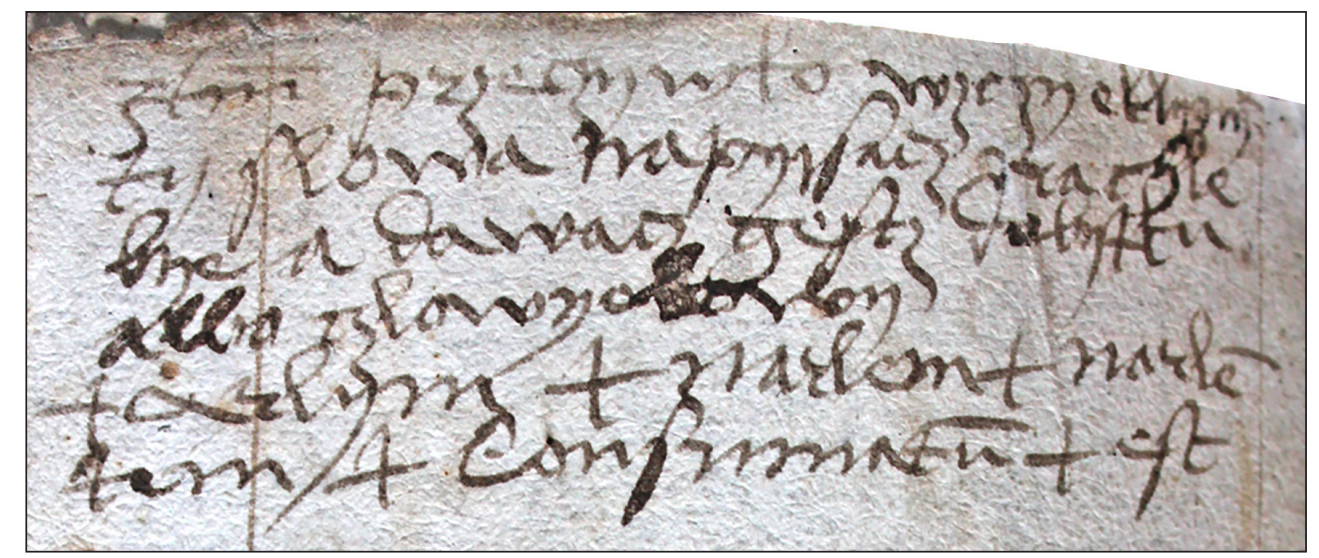

Fragment k. 192v

17 Zasady wydawania tekstów staropolskich. Projekt, red. K. Górski i in., Wrocław 1955. Jedyna różnica polega na nieznakowaniu w transliteracji odmiennych grafemów głosek: $s$ (w rkpsie występują: $s$ zwykłe, $s$ długie i grecka sigma) oraz $r$ (w rkpsie występują: $r$ zwykłe i $r$ francuskie). 


\section{TRANSLITERACJA}

k. $192 \mathrm{r}^{18}$

15 Contra venenosos vermes polovz nozny palecz wyelky nalewy Tedy movwyz po trzykrocz wyerze Bogą potym gestlyz gest gąd albo gadzycza styr albo sczyrzycza

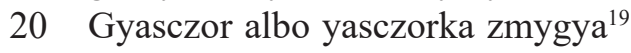
albo zmygycza pzykazvye tobye boza $^{\mathrm{n}} \mathrm{z}^{20}$ mocza $^{\mathrm{n}}$ aby temvto bozemv stworzenyv nycz aby nye skodzylo a mą myanowacz ten rzecz mya

25 nem kogo by ten cg robąk vsczy pnąl In nomine patris et fily et spiritus sanctus ${ }^{21}$ amen

\section{k. $192 \mathrm{v}$}

Item przeczywko wzczyeklyznye ty slowa napysacz na chle bye a dawacz gescz dobytku albo czlowyekowy

$5+$ Arlym $^{22}+$ narlem + narle $^{\mathrm{m}}$ tem $^{23}+$ Consumatum + est
18 Tekst zaklęcia zaczyna się od w. 15. Poprzedzony jest dwiema formułami łacińskimi: Contra tonitrua, Benediccio panis.

${ }^{19}$ zmygya: tak w rkpsie.

${ }^{20}$ bozan $^{\mathrm{n}} \mathrm{z}$ : w rkpsie wyraźny łuczek nad $-a-$.

${ }^{21}$ sanctus: tak w rkpsie zam. sancti.

22 Arlym: możliwa też lekcja arlym.

${ }^{23}$ narlemtem: możliwa też lekcja narlentem; z uwagi na wcześniejszy wyraz narlem, skrót rozwiązano z literą m.

\section{TRANSKRYPCJA}

k. 192 r

Contra venenosos vermes

Połouż ${ }^{24}$ nożny palec wielki na lewy, tedy mouwiż ${ }^{25}$ po trzykroć: „Wierzę Boga". Potym, jestliż jest gad albo gadzica, sztir ${ }^{26}$ albo szczyrzyca, jaszczor albo jaszczorka, źmij[a] ${ }^{27}$ albo źmijica, przykazuję tobie bożąż mocą, aby temu to bożemu stworzeniu nic aby nie szkodziło. A ma mianować ten, rzec mianem ${ }^{28}$, kogo by tenci robak uszczypnął: In nomine Patris et Filii et Spiritus Sancti. Amen.

k. 192 v

Item przeciwko wściekliźnie ty słowa napisać na chlebie a dawać jeść dobytku albo człowiekowi:

+ Arlim + narlem + narlemtem

+ Consumatum + est $^{29}$.

${ }^{24}$ połouż: bohemizm.

${ }^{25}$ mouwiż: bohemizm.

${ }^{26}$ sztir: bohemizm.

${ }^{27} \mathrm{Z}$ uwagi na regularną opozycję męska forma do żeńskiej (zob. dalej) zapis źmija został rektyfikowany, choć może należałoby pozostawić formę źmija.

${ }^{28}$ Dziękuję prof. IJP PAN, dr hab. Ewie Deptuchowej za zwrócenie mi uwagi na różne możliwości interpretacyjne. O wariantach interpretacyjnych zob. dalej.

29 Consumatum est: 'dokonało się’ stała formuła występująca w inkantacjach i modlitwach, por. Jo 19,30.

Grafia powyższych zapisów jest typowa dla zabytków językowych pierwszej połowy XV w. Uwidacznia się to głównie na poziomie grafemów, które są wielofunkcyjne. Jeden grafem mógł być użyty do oznaczenia różnych głosek, np. grafem $z$ oznacza głoski $z, \dot{z}, \dot{z}, \dot{s}$. Tekst inkantacji, jak wspomniano na początku artykułu, zapisany został pod koniec XV w., gdy staropolskie zabytki językowe odznaczały się już znaczną regularnością zapisu, np. rozróżniano w nich nosówki, spółgłoski syczące i szumiące, poszczególne grafemy regularnie stosowano na oznaczenie określonych głosek. Istnieje zatem rozbieżność między stosowaną praktyką piśmienniczą zaklęć a ich chronologią. Uwidacznia się to jeszcze bardziej w szczegółowej analizie. Wśród najważniejszych cech grafii obu zaklęć należy wymienić:

\section{Samogłoski}

1) na oznaczenia samogłosek nosowych pisarz używa grafemów $a, a, e$. Nosówka przednia zapisana jest za pomocą grafemu $e$ : wyerze, a nosówka tylna za pomocą grafemów a: vsczypnąl oraz a z łuczkiem nad literą, oznaczającym połączenie liter an: bozanz, moczan; 
2) trzykrotnie użyto grafemu $a$ na oznaczenie głoski $a$ : Boga, gad, $m a$;

3) głoska $u$ oznaczana jest przez grafemy $v, o, u$ oraz trudne do jednoznacznej interpretacji ov;

a) grafem $v$ na oznaczenie głoski $u$ : przykazvye, temv, bozemv, stworzenyv, vsczypnal,

b) grafem o na oznaczenie głoski $u$ : gyasczor, yasczorka,

c) grafem $u$ na oznaczenie głoski $u$ : dobytku,

d) grafem $o v \mathrm{w}$ zależności od przyjętej interpretacji może oznaczać głoskę $u$ - jeżeli uznać to połączenie za oznakę pochylenia lub połączenie głosek ou - z uwagi na śląskie pochodzenie rękopisu i wpływ języka czeskiego: polovz, movwyz;

4) głoski $i, y$,

a) głoska $i$ oznaczana jest wyłącznie przez grafem $y$, np.: wyelky, napysacz, czlowyekowy,

b) głoska $y$ oznaczana jest wyłącznie przez grafem $y$ : nozny, lewy, tedy, trzykrocz, potym, sczyrzy$c z a, a b y, a b y, b y$, ty, dobytku.

\section{Spólgłoski}

1) konsekwentne oznaczanie miękkości spółgłoski przed samogłoską przez grafem $y$, np.: wyelky, wyerze, tobye, stworzenyv, myanowacz, wzczyeklyznye, czlowyekowy;

2) konsekwentne oznaczanie miękkości spółgłoski przed spółgłoską przez grafem y, np.: gadzycza, styr, $n y c z$, przeczywko, wzczyeklyznye, napysacz. Jedynym wyjątkiem jest zapis partykuły cg, w którym miękkość oznaczono grafemem $g$;

3) brak graficznego rozróżnienia spółgłosek szeregu s - š - ś. Pisarz stosuje następujące grafemy na oznaczenie głosek tego szeregu:

a) grafem $s$ na oznaczenie głoski $s$ : gestlyz, stworzenyv, slowa, napysacz,

b) grafem $s$ na oznaczenie głoski š: styr, sczyrzycza, gyasczor, yasczorka, skodzylo, vsczypnal,

c) grafem $s$ na oznaczenie głoski ś: gescz,

d) grafem $z$ na oznaczenie głoski $z$ : pzykazvye,

e) grafem $z$ na oznaczenie głoski ž: polovz, nozny, movyz, gestlyz, pzykazvye, bozaz, bozemv,

f) grafem $z$ na oznaczenie głoski ź: wzczyeklyznye, zmygya, zmygycza,

g) $z$ na oznaczenie głoski ś: wzczyeklyznye;

4) wielofunkcyjność grafemu $c z$ dla spółgłosek szeregu $c-\check{c}-\dot{c}$,

a) grafem $c z$ na oznaczenie głoski $c$ : palecz, gadzycza, sczyrzycza, zmygycza, mocza, nycz, rzecz,

b) grafem $c z$ na oznaczenie głoski č: sczyrzyca, gyasczor, yasczorka, vsczypnal, czlowyekowy,

c) grafem $c z$ (również $c z \mathrm{~W}$ połączeniu z y) na oznaczenie głoski ć: trzykrocz, myanowacz, przeczywko, wzczyeklyemu, napysacz, dawacz, gescz;

5) grafem $w$ na oznaczenie głoski w: wyelky, lewy, wyerze, stworzenyv, myanowacz, przeczywko, wzczyeklyemu, slowa, dawacz, czlowyekowy;

6) głoska $j$ oznaczana jest głównie przez grafem g: gestlyz, gest, gyasczor, zmygycza, gescz. Kłopotliwym $\mathrm{w}$ interpretacji zapisem jest zmygya, w którym znajduje się naddatek graficzny w postaci $a$, ponieważ w tym miejscu należałoby się spodziewać staropolskiej postaci źmij. W tekście zaklęcia występuje regularna opozycja stworzeń męskich do żeńskich ${ }^{30}$. Poza tym w jednym wypadku głoska $j$ oddana została przez grafem y: yasczorka.

W zapisach obu zaklęć nie widać różnic graficznych. Zaskakujące jest w nich wspomniane powyżej połączenie nieregularności przejawiającej się na poziomie oznaczania głosek, charakterystycznej dla pierwszej połowy XV w., z regularnością w oznaczaniu miękkości stosowaną od połowy XV w. Wytłumaczeniem tego zjawiska może być istnienie wcześniejszego źródła, z którego sporządzono kopię inkantacji do dominikańskiego kolektarza, przy jednoczesnym uwspółcześnianiu przez pisarza postaci

${ }^{30}$ Tego typu opozycje można odnaleźć w innych zaklęciach, np.: Wymawiam was Boża moca, Pana Boga pomoca, Węże, wężyce, żmije, żmiice, padalce i padalczyce i wszelki robaku!; por. „Wisła. Miesięcznik Geograficzno-Etnograficzny”, 19, 1905 , s. 558. 
tekstu do formy, jaką znał i stosował. Gdyby brać pod uwagę tę propozycję wyjaśnienia zaistniałego zjawiska graficznego, należy zauważyć, że śladów dawnych praktyk pisarskich (z początku XV w.) jest w obu tekstach niewiele. Wśród nich można niewątpliwie wymienić dwa: przytaczaną już wielofunkcyjność występujących grafemów spółgłoskowych i zastosowanie skrótów w trzech wyrazach: gest (gt z łuczkiem nad nimi), bozanz, moczan (łuczek nad $a$ oznaczający połączenie głosek an). W omawianych zabytkach brakuje jednak cech charakterystycznych dla pisma z początku czy połowy XV w., np. połączenia grafemów th na oznaczenie głoski $t$, niekonsekwentnego oznaczania miękkości, nierozróżniania nosówki przedniej i tylnej. Oba teksty przedstawiają nowszą formę zapisu, czego dowodem może być np. regularne stosowanie rz: trzykrocz, wyerze, sczyrzycza, stworzenyv, rzecz, przeczywko (jedynym odstępstwem jest postać pzykazvye). Sumując tych kilka cech grafii, występujących w zaledwie 18 krótkich wierszach, należy stwierdzić, że pod tym względem inkantacje są zabytkami zbliżonymi w swojej postaci do tekstów z końca XV lub nawet początku XVI w.

Równie ciekawe jak grafia zabytku jest jego słownictwo, ponieważ język dominikańskich zaklęć kryje w sobie nie tylko wyrazy i formy wyrazowe, których nie przechowały inne zabytki języka staropolskiego, ale także leksemy świadczące o jego regionalnej przynależności. Cennym uzupełnieniem do materiałów Słownika staropolskiego [dalej: Sstp] są cztery leksemy: miano, źmijica, uszczypnąć, wścieklizna.

Rzeczownik miano w znaczeniu 'imię własne, nazwa osobowa' znany był dotychczas z materiałów zebranych przez Słownik polszczyzny XVI wieku [dalej: SPXVI]. Wśród XV-wiecznych leksemów należących do jego rodziny wyrazowej Sstp odnotował mianowanie występujące w trzech znaczeniach, z czego najbliższe jest 1. 'nazwa' oraz czasownik mianować, który w znaczeniu 4. 'zawołać po nazwisku (imieniu), wywołać, przywołać' zbliżony jest do zwrotu występującego w zaklęciu Contra venenosos vermes. XV-wieczny zwrot: rzec mianem można dziś tłumaczyć: 'nazwać coś lub kogoś po imieniu'.

Drugi rzeczownik źmijica utworzony został przez dodanie formantu -ica ${ }^{31}$ do znanego średniowiecznej polszczyźnie rzeczownika źmij, przytaczanego w Sstp z Psałterza puławskiego (Puł 90,13) w znaczeniu 'jadowity gatunek węża'. Źmijica byłaby zatem 'samicą jadowitego węża', utworzoną na wzór gołębicy, lwicy czy wyżlicy.

Czasownik uszczypnąć, choć należy do kanonicznych haseł SPXVI, to nie był dotąd znany ze średniowiecznych zabytków języka polskiego. Wystąpienia czasowników szczypać, uszczypać, czy jednokrotnych szczypnać, uszczypnać, można się było spodziewać w tekstach średniowiecznych, ponieważ znane są staropolszczyźnie leksemy pochodzące od nich, np. przymiotnik szczypnęty oraz rzeczownik szczyptki. W zaklęciu przeciw jadowitym robakom czasownik uszczypnąć użyto $\mathrm{w}$ znaczeniu 'ukąsić, ugryźć'.

Rzeczownik wścieklizna, jak podaje w Słowniku etymologicznym A. Brückner, notowany był już w XVI w. Niestety indeks SPXVI nie potwierdza tego, co nie oznacza, że wyraz ten nie był wtedy używany. Z polskich słowników pierwszy raz poświadcza go Samuel Bogumił Linde w Słowniku języka polskiego, w znaczeniu 'wścieczenie się, bycie wściekłym', z uwzględnieniem występującej oboczności wścieklina, wścieklizna, z uściśleniem 'choroba właściwa psom'. Sstp odnotował jedynie czasownik wściekać się oraz przymiotnik wściekty. Wścieklizna z rękopisu dominikańskiego jest zatem najstarszym znanym zapisem tego leksemu.

W trzech innych wypadkach dokumentacja Sstp nie obejmuje fleksyjnych form leksemów odnotowanych w inkantacjach: lewy, napisać, szkodzić. Modlitwy przynoszą także kolejne potwierdzenia występowania wyrazów w znaczeniu i formie udokumentowanej przez Sstp, np.: stworzenie $-d$. sg. tego rzeczownika w Sstp cytowany jest tylko z Mammotrektu lubińskiego (1471 r.), jaszczór - n. sg. z wypisów Józefa Rostafińskiego (1472), jaszczórka - n. sg. również z wypisów Rostafińskiego (1472), gad - n. sg. z traktatu o ortografii polskiej Jakuba Parkosza (1460). W innym znaczeniu udokumentowana jest w Sstp szczyrzyca: 1. 'szczyr roczny', 2. 'szarłat pospolity', jednak żadne z powyższych nie odpowiada temu, które znajduje się w zaklęciu. W tekście inkantacji szczyrzyca oznacza 'samicę skorpiona' i jest to bohemizm utworzony od czeskiego rzeczownika štir za pomocą sufiksu $-y c a^{32}$.

${ }^{31}$ Por. K. Kleszczowa, Stowotwórstwo języka doby staropolskiej. Przegląd formacji rzeczownikowych, Katowice 1996, s. 49-59.

${ }^{32}$ Por. tamże, s. 49-59. 
Jak wspomniano na początku artykułu, do Krakowa manuskrypt przybył z dominikańskiego klasztoru w Raciborzu, a prawdopodobnie jeszcze wcześniej należał do klasztoru we Wrocławiu. Ślady śląskiego pochodzenia można odnaleźć nie tylko w łacińskich notach, eksplicitach czy też zapiskach proweniencyjnych, ale również w słownictwie zaklęć. Pojawiają się w nim bowiem bohemizmy leksykalne: gadzica i štir.

Pierwszy leksem gadzica mógł być pożyczką z języka czeskiego, w którym występowała forma hadicě 'wąż, samica węża' ${ }^{33}$ lub z rozpowszechnionego na obszarze Śląska języka niemieckiego, w którym wyraz ten miał postać haditze (inne jego formy to: heptisse, eidechse) i oznaczał 'jaszczurkę'34. Nie ma jednak pewność, czy gadzica była bezpośrednią pożyczką, czy może żeńską postacią znanego w staropolszczyźnie leksemu gad, od którego za pomocą sufiksu -ica mogła powstać forma gadzica, podobnie jak istniały węda - wędzica. Słowo gadzica funkcjonowało w gwarach polskich jeszcze na początku ubiegłego stulecia ${ }^{35}$. W jednej z ludowych opowieści można przeczytać o przychylnych człowiekowi gadzicach:

Jeśli człowiek leży na ziemi i śpi, a jadowita gadzina przyczołgała się w jego pobliże, to gadzica wbiega na pierś i twarz człowieka, by go zbudzić, ostrzegając przed niebezpieczeństwem w ten sposób. Jeśli kto jednak gadzicę rozjątrzy, to staje się bardzo złą i od razu kąsa dziewięć razy, z czego powstawało dziewięć ran. Goją się one co roku jedna. Gdy atoli zagoiła się rana siódma, wówczas człowiek musi umieraćc ${ }^{36}$.

W tekście średniowiecznej inkantacji nie chodziło jednak o rozróżnienie złej gadziny od przychylnej człowiekowi gadzicy, ale o przeciwstawienie samca i samicy. W zestawieniu jadowitych robaków występujących w zaklęciu uwidacznia się opozycja męski - żeński: gad - gadzica, štir - szczyrzyca, jaszczór - jaszczórka, źmij $[a]$ - źmijica.

Drugim bohemizmem jest štir 'skorpion' (Stownik staroczeski) oraz utworzona od niego żeńska postać szczyrzyca. Podobnie jak w przykładzie pierwszym, nie można jednoznacznie stwierdzić, czy wymienione wyrazy funkcjonowały jako czeskie, czy polskie, ponieważ słownictwo mieszkańców Śląska charakteryzowało się wymiennością stosowania leksemów z zasobów języka polskiego, czeskiego i niemieckiego ${ }^{37}$.

Wyjaśnienie znaczeń poszczególnych wyrazów, choć ułatwia zrozumienie dawnego tekstu, to nie zawsze prowadzi do właściwej interpretacji. Zaklęcia z założenia były tekstami hermetycznymi, przeznaczonymi dla wybranych osób, a przez to trudnymi do jednoznacznego zinterpretowania dla kogoś postronnego. Po ponad pięciuset latach niełatwo właściwie odczytywać zapisane w kolektarzu inkantacje. Pojawiają się odmienne możliwości interpretacyjne wynikające m.in. z wariantywności graficznej, braku interpunkcji w tekście czy traktowania pojedynczych wyrazów jako potencjalnych glos.

Przykładem takiego trudnego do zrozumienia miejsca jest fragment: a ma myanowacz ten rzecz myanem kogo by ten cg robąk vsczypnąl. Forma zapisu sprawia, że współcześnie można go przetłumaczyć na kilka sposobów. Poniżej prezentuję trzy różne objaśnienia tego fragmentu.

Pierwsza możliwość interpretacyjna: A ma mianować ten, rzec mianem, kogo by tenci robak uszczypnąt. Opiera się ona na odczytaniu zwrotu rzec mianem 'przywołać po imieniu' jako glosy objaśniającej do poprzedzającego ją czasownika mianować 'powiedzieć, zawołać' i wskazaniu zależności między zaimkami ten - kogo: ten, kogo by tenci robak uszczypnąt.

Druga propozycja wyklucza traktowanie zapisu ten rzecz jako glosy do myanowacz. Odczytanie, podobnie jak w pierwszym wypadku, opiera się na wskazaniu zależności między zaimkami, tu dodat-

${ }_{33}$ Por. Stownik staroczeski, <http://vokabular.ujc.cas.cz/> [dostęp 25.07.2017].

${ }^{34}$ Por. Wörterbuchnetz, <http://woerterbuchnetz.de/> [dostęp 25.07.2017]; J. Ulrich, Volkssagen aus Pommern und Rügen, Stettin 1886, s. 487.

${ }_{35}$ H. Biegeleisen, Lecznictwo ludu polskiego, Kraków 1929, s. 405.

36 „Lud. Organ Towarzystwa Ludoznawczego we Lwowie”, 8, 1902, s. 307, <http://www.wbc.poznan.pl/Content/120639/ index.djvu> [dostęp 25.07.2017].

${ }^{37}$ Por. K. Borowiec, Średniowieczne teksty interferowane, w: Juwenalia historycznojęzykowe. 1, Poznań 2015, s. 9-24. 
kowo wzmocnionymi partykułami tenżeć a tenci: A ma mianować tenżeć mianem, kogo by tenci robak uszczypnąt. Poważną wątpliwość budzi jednak zapis głoski $\check{z}$ występującej w partykule -że- za pomocą dwuznaku -rz-. W całym tekście pisarz na oznaczenie tej głoski regularnie stosował grafem $z$. Równie trudnym do zinterpretowania $\mathrm{w}$ tym zdaniu jest zwrot mianem mianować. Podobny zwrot: mianem mianować się ‘nazywać się imieniem' używany był w polszczyźnie XVI-wiecznej. Nie można jednak wykluczyć, że jego postać bez zaimka zwrotnego mogła funkcjonować równolegle lub wcześniej w znaczeniu podobnym do innego XVI-wiecznego zwrotu: mianować imię (imię mianować) 'wzywać imienia', np. ten mianuje imię Christusowe (SPXVI, t. 13, s. 340). W takim wypadku fragment ten można by rozumieć: A tenżeć ma wzywać imienia, kogo by tenci robak uszczypnąt.

Ostatni sposób przybliżenia zagadkowego fragmentu opiera się na odmiennym odczytaniu wyrazu myanowacz. W dwóch pierwszych propozycjach interpretowano go jako czasownik mianować, ale może być również czytany jako rzeczownik mianowacz. Staropolszczyzna zna wiele rzeczowników z formantem -acz pochodzących od czasowników, np. budowacz, ciądzacz, gadacz, jednacz, kłamacz ${ }^{38}$. Gdyby przyjąć, że w inkantacji najpierw wskazany jest wykonawca czynności mianowacz 'ten kto nazywa, wymawia', a następnie opisana jest wykonywana czynność, otrzymalibyśmy: A ma mianowacz ten rzec mianem, kogo by tenci robak uszczypnąt. Więcej kłopotu nastręcza zwrot rzec mianem, bo należałoby go rozumieć nie - jak wcześniej proponowano - 'nazywać imieniem', ale 'mówić w imieniu' tego, kogo robak uszczypnął, a potwierdzenia takiego użycia w materiałach staropolskich nie odnajdujemy.

Analiza tego niewielkiego fragmentu pokazuje, jak trudno współczesnemu badaczowi dotrzeć do intencji piszącego. Brak staropolskich tekstów o podobnej tematyce, strukturze i leksyce nie pozwala na ściślejsze dointerpretowanie takich miejsc, które są szczególnie niezrozumiałe. Bez wątpienia odnalezione zaklęcia są cennym znaleziskiem kulturowym i językowym, zasługującym na wprowadzenie ich do obiegu naukowego oraz umożliwienie innym podjęcia odmiennych od zaprezentowanych powyżej prób interpretacji.

38 W SPXVI mianowacza odnotowano jedynie w znaczeniu matematycznym jako 'mianownik'. 


\section{INDEKS}

$\mathrm{A}-a$ 192r/24; 192v/3.

ABY - I spójnik aby 192r/22; II partykuła aby $192 \mathrm{r} / 23$.

ALBO - albo 192r/18. 19. 20. 21; 192v/4.

BOŻY - d. sg. neutr. bozemv 192r/22; i. sg. f. bozan $192 \mathrm{r} / 22$.

BÓG - ac. sg. Boga 192r/18.

$\mathrm{BY}-$ by $192 \mathrm{r} / 25$.

BYĆ - praes. ind. 3. sg. gest 192r/18.

CHLEB - 1. sg. (na) chlebye 192v/2.

-CI - tencg 192r/25.

CZŁOWIEK - d. sg. czlowyekowy 192v/4.

DAWAĆ - inf. dawacz 192v/3.

DOBYTEK - d. sg. dobytku 192v/3.

GAD - n. sg. gad 192r/18.

GADZICA - n. sg. gadzycza 192r/19.

JASZCZUR - n. sg. Gyasczor 192r/20.

JASZCZURKA - n. sg. yasczorka 192r/20.

JESTLI - gestly 192r/18.

JEŚĆ - inf. gescz 192v/3.

KTO - ac. sg. kogo 192r/25.

LEWY - ac. sg. m. lewy 192r/16.

MIANO - i. sg. myanem 192r/24/25.

MIANOWAĆ - inf. myanowacz 192r/24.

MIEĆ - praes. ind. 3. sg. ma 192r/24.

MOC - i. sg. moczan $192 \mathrm{r} / 22$.

MÓWIĆ - imper. 2. sg. movwy 192r/17.

NA - cum ac. na 192r/16; cum 1. na 192v/2.

NAPISAĆ - inf. napysacz 192v/2.

NIC - nycz 192r/23.

NIE - nye 192r/23.
NOŻNY - ac. sg. m. nozny 192r/16.

PALEC - ac. sg. palecz 192r/16.

PO - cum ac. po trzykroć 192r/17.

POŁOŻYĆ - imper. 2. sg. polovz 192r/16.

POTYM - potym 192r/18.

PRZECIWKO - cum dat. przeczywko 192v/1.

PRZYKAZOWAĆ - praes. ind. 1. sg. pzykazvye $192 \mathrm{r} / 21$.

ROBAK - n. sg. robak 192r/25.

RZEC - inf. rzecz 192r/24.

SŁOWO - ac. pl. slowa 192v/2.

STWORZENIE - d. sg. stworzenyv 192r/23.

SZCZYRZYCA - n. sg. sczyrzycza 192r/19.

SZKODZIĆ - condit. 3. sg. neutr. -by skodzylo $192 \mathrm{r} / 23$.

SZTIR - n. sg. styr 192r/19

TEDY - Tedy 192r/17.

TEN - n. sg. m. ten 192r/24, 192r/25; d. sg. neutr. temv 192r/22; ac. pl. neutr. ty 192v/2.

TO - partykuła to $192 \mathrm{r} / 22$.

TRZYKROĆ - trzykrocz 192r/17.

TY - dat. tobie 192r/21.

USZCZYPNĄĆ - condit. 3. sg. m. by vsczypnal $192 \mathrm{r} / 25$.

WIELKI - ac. sg. m. wyelky 192r/16.

WIERZYĆ - praes. ind. 1. sg. wyerze 192r/17.

WŚCIEKLIZNA - d. sg. wzczyeklyznye 192v/1.

ŹMIJ - n. sg. zmygy[a] 192r/20.

ŹMIJICA - n. sg. zmygycza 192r/21.

-Ż - movwyz 192r/17; gestlyz 192r/18; bozanz $192 \mathrm{r} / 22$. 


\section{Two old-Polish incantations of the fifteenth century}

Summary: The fifteenth-century manuscript no. R. XV. 3 belonging to the Archive of the Polish Province of Dominican Fathers in Cracow contains magic formulas (pages 192r-193v). These are so-called 'incantationes': against a rabid dog, against a rabid dog bite, against a thunder, against all the poison, against venomous worms and against rabies (Contra rabiem venenosi canis, Contra morsum rabidi canis, Contra toniturua, Benediccio panis pro pecudibus... contra omnem venenum, Contra venenosos vermes, Contra rabies). The last two of them is unique because it was written in Polish. Up to now, only three other medieval magic spells written in Polish were known to us. They were published in 1895 by Aleksander Brückner in Volume XXIV of Rozprawy Akademii Umiejętności.

The incantations against venomous worms and against rabies are a valuable monuments of the Old Polish language not only due to the nature of this texts, but also because of the fifteenth-century words and word forms that were unknown until now. This small size formulas is a linguistic testimony of medieval medical practices and an expression of faith in God combined with superstitious beliefs.

Nota o Autorze: dr Mariusz Leńczuk, absolwent Instytutu Filologii Polskiej UAM w Poznaniu. Od 2002 r. zatrudniony w Pracowni Języka Staropolskiego Instytutu Języka Polskiego PAN w Krakowie. Od 2009 r. adiunkt w Pracowni Języka Staropolskiego IJP PAN w Krakowie. Zainteresowania naukowe: XV-wieczne zapisy polskie w rękopisach łacińskich, średniowieczne tłumaczenia Biblii, paleografia średniowieczna, leksykografia historyczna, synonimia staropolska. Udział w projektach badawczych oraz spis najważniejszych publikacji naukowych: https:// pjs.ijp.pan.pl/ml.html.

Author: Mariusz Leńczuk, PhD, graduate of the Polish Philology Institute of the Adam Mickiewicz University in Poznań. Since 2002 member of the History of the Polish Language Department at the Institute of the Polish Language at the Polish Academy of Sciences in Cracow. Since 2009 assistant of the Old Polish Language Section at the Institute of the Polish Language at the Polish Academy of Sciences in Cracow. Scientific interests: $15^{\text {th }}$-century Polish records in Latin manuscripts, medieval Bible translations, medieval paleography, historical lexicography, Old Polish synonymy. Participation in research projects and a list of the scientific publications: https://pjs.ijp.pan.pl/ml.html.

Instytut Języka Polskiego PAN

al. Mickiewicza 31

31-120 Kraków

e-mail: mariusz.lenczuk@ijp-pan.krakow.pl

\section{Bibliografia}

Basaj M., Siatkowski J., Bohemizmy w języku polskim. Słownik, Warszawa 2006

Biegeleisen H., Lecznictwo ludu polskiego, Kraków 1929

Borowiec K., Średniowieczne teksty interferowane, w: Juwenalia historycznojęzykowe. 1, Poznań 2015, s. 9-24

Boryś W., Słownik etymologiczny języka polskiego, Kraków 2005

Bracha K., Pismo, stowa i symbole. Pomiędzy średniowieczna pobożnościa a magia, w: Inskrypcje toruńskie, red.

I. Sawicka, Toruń 1999, s. 7-24

Brückner A., Kazania średniowieczne, cz. 2, w: Rozprawy Akademii Umiejętności. Wydział Filologiczny, t. 24, Kraków 1895, s. 317-390

Brückner A., Stownik etymologiczny języka polskiego, Kraków 1927

Czernik S., Trzy zorze dziewicze. Wśród zamawiań i zaklęć, Łódź 1968 (wyd. 2, 1985)

Derolez A., The Palaeography of Gothic Manuscript Books. From the Twelfth to the Early Sixteenth Century, Cambridge 2003

Engelking A., Rytuaty stowne w kulturze ludowej. Próba klasyfikacji, w: Język a kultura, t. 4: [Funkcje języka $i$ wypowiedzi], red. J. Bartmiński, R. Grzegorczykowa, Wrocław 1991, s. 75-85

Falimirz S., O ziołach i o mocy ich, Kraków 1534, <http://www.dbc.wroc.pl/dlibra/docmetadata?id=2228\&from=publication> [dostęp: 25.07.2017]

Jankowiak L.A., Stownictwo medyczne Stefana Falimirza, t. 1-2, Warszawa 2005-2006 
Karolińscy pokutnicy i polskie średniowieczne czarownice. Konfrontacja doktryny chrześcijańskiej z życiem społeczeństwa średniowiecznego, red. M. Koczerska, Warszawa 2007

Kleszczowa K., Stowotwórstwo języka doby staropolskiej. Przegląd formacji rzeczownikowych, Katowice 1996

Kleszczowa K., Staropolskie derywaty przymiotnikowe i ich perspektywiczna ewolucja, Katowice 2003

Leśniewska-Sawicka M., Waśkow M., Medycyna ludowa, gusła i zabobony jako metody lecznicze praktykowane w XXI wieku, „Medycyna Rodzinna”, 15, 2012, nr 1, s. 10-14

Linde M.S.B., Słownik języka polskiego, t. 1-6, Lwów 1856-1860

„Lud. Organ Towarzystwa Ludoznawczego we Lwowie”, 8, 1902, <http://www.wbc.poznan.pl/Content/120639/ index.djvu> [dostęp 25.07.2017]

Nowak K., Jak dawniej leczono, czyli o akcie siedemnastowiecznej porady medycznej, w: Bogactwo polszczyzny $w$ świetle jej historii, t. 2, red. K. Kleszczowa, A. Rejter, Katowice 2008, s. 119-130

Siekierka H.I., Notacje monodii chorałowej na Ślasku na podstawie kodeksów Biblioteki Kapitulnej we Wrocławiu. Studium paleograficzno-semiologiczne, Lublin 2011

Słownik polszczyzny XVI wieku, t. 1-36, red. M.R. Mayenowa, K. Mrowcewicz, Wrocław-Warszawa 1966-2012, $<$ http://kpbc.umk.pl/publication/17781> [dostęp 25.07.2017]

Słownik staroczeski/Vokabulár webový, < http://vokabular.ujc.cas.cz/> [dostęp 25.07.2017]

Słownik staropolski, t. 1-11, red. S. Urbańczyk, Warszawa-Kraków 1953-2002, <http://www.pjs.ijp-pan.krakow. $\mathrm{pl} / \mathrm{sstp} . \mathrm{html}>$ [dostęp 25.07.2017]

Szostak J., Vademecum lecznictwa domowego z roku 1563, Brzezia Łąka 2016

Ulrich J., Volkssagen aus Pommern und Rügen, Stettin 1886

„Wisła. Miesięcznik Geograficzno-Etnograficzny”, 19, 1905

Włodarski M., Polska poezja świecka XV wieku, wyd. 4 zm., Wrocław 1997

Wörterbuchnetz, <http://woerterbuchnetz.de/> [dostęp 25.07.2017]

Zasady wydawania tekstów staropolskich. Projekt, oprac. K. Górski i in., Wrocław 1955 